\title{
Nothing is certain... A comment on uncertainty, objectivity and scientism
}

The old saying goes "nothing is certain but death and taxes." The origin of this rather fatalistic and sardonic proverb in English draws on the actual inevitability of death to highlight the difficulty in avoiding the burden of taxes. Several famous authors have uttered lines to this effect. The first was Daniel Defoe, in The Political History of the Devil, 1726: "Things as certain as death and taxes, can be more firmly believed." Benjamin Franklin (1706-90) used the version with which we are currently more familiar, in a letter to Jean-Baptiste Leroy, 1789, which was reprinted in The Works of Benjamin Franklin, 1817: "Our new Constitution is now established, and has an appearance that promises permanency; but in this world nothing can be said to be certain, except death and taxes." In Spanish, this proverb is used to indicate that, notwithstanding a person's social status, no one escapes taxes -nor eventually death. In Argentina, in particular, other phrase is used to express that nobody can avoid something happening to them, good or bad. ${ }^{1}$

Likewise, medicine cannot escape its own obligation to "pay taxes" for its alleged objectivity and false certainty, combined with its scientism. Medicine has become mired in the Positivism and Logical Positivism or Inherited Conception (IC) paradigm, founded by the Vienna Circle in the 1920s. ${ }^{2}$ The assumptions of this school of thought include:

- Empiricism: Positivism posed that positive knowledge (empirical, objective knowledge with formalization of phenomena) was the only valid method to access knowledge.

- Rationalization: It reduces reason to science. Scientific knowledge is not only the greatest and most complete archetype of human reason, it is also the only plausible reasoning.

- Reductionism: Inherited conception proposes methodological unity, keeps faith in the scientific method, holds that access to knowledge is the same for any type of knowledge. This means that physics is the model for knowledge.

- Rejection of metaphysics: Inherited conception aims at freeing itself from the troubles related to knowledge production. It is not interested in the origin of scientific knowledge or the context of discovery because that is a problem for sociology, history or psychology. Inherited conception deals with the rationale or validity of hypotheses and the context of rationale through: empirical control (by means of the senses) of its first-level statements, and logical validity, i.e. the correction of the deductive process that relates essential hypotheses to empirical statements. The fact that these are the only means to decide whether a scientific theory is true or false aids in understanding one of positivism's basic conditions for scientific knowledge: objectivity. Thus, the position of the Circle of Vienna was anti-methaphysics.

A distinguishing feature of logical positivism is its widely reductionist nature. It reduces certain sciences into others, restricts relevant human knowledge to that originating from an empirical approach, attempts to reduce methodological diversity to unity, and lastly establishes a doubly reductionist ideological strategy: it reduces rationality to science, and science to purely methodological aspects (logical and empirical control of scientific theories).

Deficiencies related to this theoretical framework became evident rapidly, and the first criticisms emerged from its own flagship: physics. The second law of thermodynamics ${ }^{3}$ demolished the concept of process reversibility, and Heisemberg's uncertainty principle ${ }^{4}$ buried all claims of absolute certainty. Certainty is closely related to entropy, i.e., the degree of disorder in a system. The term entropy comes from the Greek em (in, about) and sqopg (a turning, transformation, change) and represents a measure unit. In physics, it applies to the second law of thermodynamics, according to which isolated systems tend towards disorder, meaning things have a tendency to become chaotic (as is the case with the bodies of living creatures). Entropy is null if certainty is absolute, and will reach its peak when systems approach balance. Once maximum entropy is reached, in other words, once there is balance between all temperatures and pressures, the heat death of the universe will occur. ${ }^{5}$ A key concept is observed here: death is certain and, in opposition, life is uncertain, changes and poses a risk.

Our society is obsessed, as part of the legacy of inherited conception, with reaching certainty 
and control. This is the society of the panopticon designed by Bentham ${ }^{6}$ (originally a prison design) and described by Foucault ${ }^{7}$ in Discipline and Punish. The present world forces people to eliminate $99.9 \%$ of germs, and thus people embark on what is a veritable crime against the environment and an unnatural fight against infectious diseases because social acceptance of an activity or product lies in its scientific origin.

Like many publicists, many physicians make certain that their advertisements or scientific texts include two magic words: scientifically proven. However, epistemology, which originates from the same inherited conception, indicates that it is not possible to prove the truth of any scientific theory. All scientific knowledge is contingent and temporal, as granted in the scientific methodology of Karl Popper's falsifiability. ${ }^{8}$ This philosophy of science states that the only proven fact in something that is scientifically proven is, basically, that it is filled with epistemological uncertainty. Even more to the point, medicine is not science: it is an art form or a discipline ${ }^{9}$ which inevitably navigates the waters of uncertainty.

As an alternative to this hegemonic point of view, Marc Jamoulle proposed a defiant concept: Quaternary Prevention (QP). ${ }^{10,11}$ This concept challenges the positivistic ideals of modern times which maintain that science and social progress are constant and always beneficial. This reminds us of Michael Foucault's positive iatrogenesis when he noted that medicine acquired the ability to damage based on its correct practice, not only due to negligence or ignorance. ${ }^{12}$ By moving away from the present concept of science, we may be able to take a distance from the idea that science only deals with knowledge and is separated from ethics and the influence of politics and economy.

$\mathrm{QP}$ arose in response to the excesses posed by medicalization, disease mongering, the equation of risk factors with disease, overdiagnosis, etc. According to QP, the underlying causes largely exceed the boundaries of medicine, and this problem includes ethical, political, economical, and science- and medicine-related aspects. For this reason, the definition of QP moved over to become a founding concept. The movement that has developed around QP has exceeded its initial biomedicine-centered definition.

QP proposes the need to establish a new model of medicine and a new pact with society. This movement ${ }^{13}$ seeks to reestablish the ethical values of medicine to make it a human activity once again, practiced by humans and in contact with life. QP does not promise certainty, there is no safe finish line, no pre-established path, no warranties; the only certainty is that we are building utopias.

Ricardo La Valle, M.D., Ph.D. Commission for Quaternary Prevention of the Argentine Federation of Family and General Medicine. lavayear@gmail.com

http:/ /dx.doi.org/10.5546/aap.2016.eng.293

\section{REFERENCES}

1. Definiciencia popular. A Seguro se lo llevaron preso. [Acceso: 2 de diciembre de 2015] Disponible en: http:// definicienciapopular.blogspot.com.ar/2008/01/segurose-lo-llevaron-preso.html.

2. La Valle R. Crisis... ¿Qué crisis? Rev Hosp Ital B. Aires 2012;32(4):158-61.

3. Eduardo C. ¿En qué consiste la segunda ley de la termodinámica? [Acceso: 28 de febrero de 2016]. Disponible en: http:/ / termodinamica-2011.blogspot.com.ar/.

4. Principio de incertidumbre. [Acceso: 28 de febrero de 2016]. Disponible en: http:/ / web.educastur.princast.es / proyectos/jimena/pj_franciscga/heisenberg.htm.

5. Entropía. [Acceso: 28 de febrero de 2016]. Disponible en: http:/ / www.artfacts.net/pdf-files/inst/entropia-prensa. pdf.

6. Neoteo. Panóptico: la cárcel más eficiente (1791). [Acceso: 28 de febrero de 2016]. Disponible en: http:/ / www.neoteo. com/panoptico-la-carcel-mas-eficiente-1791.

7. Foucault M. Vigila y Castigar: nacimiento de la prisión. Buenos Aires: Siglo XXI; 2002.

8. Gómez López R. El falsacionismo de Popper. En: Evolución científica y metodológica de la economía:escuelas de pensamiento. Eumed.net Enciclopedia virtual, 2004:33. [Acceso: 9 de marzo de 2016]. Disponible en: http: / / www.eumed.net/ cursecon/libreria/rgl-evol/rgl-metod.pdf.

9. La Valle R. Sobre ciencia, epistemología y medicina. Rev Hosp Ital B Aires 2012;32(2):51-2.

10. Jamoulle M. Information et informatisation en médecine générale. Namur, Belgium: Press Universitaries de Namur; 1986:193-209. [Acceso: 9 de marzo de 2016]. Disponible en: http:/ / orbi.ulg.ac.be/bitstream/2268/170822/1/ Jamoulle\%20-\%201986\%20-\%20Information \%20et $\% 20$ informatisation $\% 20$ en $\% 20 \mathrm{~m} \%$ C $3 \%$ A 9 decine $\% 20$ g\%C3\%A9n\%C3\%A9rale\%20Computer $\% 20$ and $\% 20$ computerisation $\% 20 \mathrm{in} \% 20$ general\%20practice $\% 282 \% 29$. pdf.

11. Jamoulle M. Quaternary prevention, an answer of family doctors to overmedicalization. Int J Health Policy Manag 2015;4(2):61-4.

12. Foucault M. La crisis de la medicina o la crisis de la antimedicina. Educ Med Salud 1976;10(2):152-6.

13. La Valle R. Prevención Cuaternaria o Medicina sin corbata. Rev Arch Med Familiar Gen 2015;12(2):5-6. 